\title{
45. CLAY MINERALOGY OF THE LOWER CRETACEOUS DEEP-SEA FAN, DEEP SEA DRILLING PROJECT SITE 603, LOWER CONTINENTAL RISE OFF NORTH CAROLINA ${ }^{1}$
}

\author{
Mary Anne Holmes, Department of Geology, Florida State University ${ }^{2}$
}

\begin{abstract}
The clay mineralogy of Lower Cretaceous deep-sea fan sediment in the western North Atlantic is dominated by smectite in most intervals, and by illite in samples from intervals of high sand input. Different intervals of high sand input are enriched in kaolinite. Kaolinite and illite levels do not correlate in this sediment, indicating that the input of each clay type was independent and represents either a different provenance or a different depositional mode. The latter hypothesis is preferred because equivalent, continental strata have clay mineral suites dominated in most cases by kaolinite, and in other cases by illite. Only marine strata of eastern North America have expandable clay. Thus under normal conditions in the Early Cretaceous, kaolinite was deposited in continental environments, illite dominated deposition in transitional environments, and smectite was transported to the deep sea. At certain intervals in the Neocomian and Aptian, fine-grained sediment bypassed the shelf and slope and enhanced Lower Cretaceous clay mineral suites in the western North Atlantic. These intervals probably corresponded to turbidity-current activity or continental flooding. Illite-enriched sediment may have been supplied by the outer shelf, whereas kaolinite-enriched intervals may have come from a more nearshore or terrestrial environment.
\end{abstract}

\section{INTRODUCTION}

Deep Sea Drilling Project reentry Hole 603B $\left(35^{\circ}-\right.$ $29.71^{\prime} \mathrm{N}, 70^{\circ} 01.71^{\prime} \mathrm{W}$ ) was drilled on the lower continental rise $270 \mathrm{n}$. mi. (435 km) east of Cape Hatteras, North Carolina, in $4642.5 \mathrm{~m}$ of water (Fig. 1). The lower portion of the hole was cored continuously through the Cretaceous section (Fig. 2) where a series of Lower Cretaceous coarse-grained siliciclastic turbidites of a deepsea fan complex were recovered from Cores $603 \mathrm{~B}-45$ to 73. The turbidites are interbedded with gray laminated nannofossil marlstone, white bioturbated limestone, and black to dark gray carbonaceous claystone turbidites (Fig. 3). The coarse clastic turbidites extend over $268 \mathrm{~m}$ of section. Turbidites of this age are known from two other Deep Sea Drilling Project sites in the western North American Basin-Sites 391 and 534 (Fig. 1); the turbidites at these localities are thinner-bedded and finer-grained than those at Site 603. No redeposited sediment was recovered in the Lower Cretaceous section at nearby DSDP Site 105 . The absence of redeposited sediment at this site may be explained by the fact that it is located over a prominent basement high, whereas DSDP Site 603 is located over a basement low. Apparently, Lower Cretaceous turbidity currents from the eastern North American margin bypassed basement highs and deposited their loads in basement lows (e.g., Sarti and von Rad, this volume).

Most clay minerals in deep-sea sediment are derived from continents with little change in the basic structure of the mineral (e.g., Biscaye, 1965). Clay-sized material is transported to the deep sea via rivers, wind, and mar-

\footnotetext{
1 van Hinte, J. E., Wise, S. W., Jr., et al., Init. Repts. DSDP, 93: Washington (U.S Govt, Printing Office). 0340 .
}

ginal processes such as slumping and turbidity currents. Clay minerals in deep-sea sediment can also be authigenic, formed by the alteration of volcanic glass, or diagenetic products of preexisting minerals (e.g., Biscaye, 1965; Millot, 1970). Detrital pelagic clay can directly reflect continental conditions. For example, Biscaye (1965) found a general relation between degree of weathering on the adjacent continent and the dominant clay mineral in Holocene Atlantic sediment. Kaolinite, usually a product of intense weathering, is the dominant clay mineral in tropic latitudes. Chlorite withstands very little weathering, and dominates the clay mineral suites of northern latitudes. Detrital illite tends to dominate elsewhere (Biscaye, 1965).

Lower Cretaceous sediment in this Basin has clay mineral suites that usually are dominated by smectite but in certain intervals are dominated by illite (Zemmels et al., 1972; Flood, 1978; Chamley, 1979; Koch and Rothe, 1979; Chamley et al., 1983). The intervals in which illite becomes more abundant are called "illitic events" by Chamley et al. (1983). In Lower Cretaceous sediment at Site 534, these occur in lower and upper Berriasian, upper Barremian-lower Aptian, and Albian intervals (Chamley et al., 1983). The dominance of smectite in western North Atlantic Lower Cretaceous sediment has led Chamley (1979) and Chamley and Robert (1982) to postulate the existence of extensive eastern North American Vertisols during the Early Cretaceous. Vertisols are characterized by a high shrink-swell capacity and sometimes have a high organic content (Soil Survey Staff, 1975). Poorly drained coastal areas, indicating tectonic stability and low continental relief, together with a hot climate characterized by strong contrasts in seasonal humidity are hypothesized to have promoted the development of these soils (Chamley and Robert, 1982).

Alternatively, deep-sea clay mineralogy may reflect different transport mechanisms of clay-sized material to the 


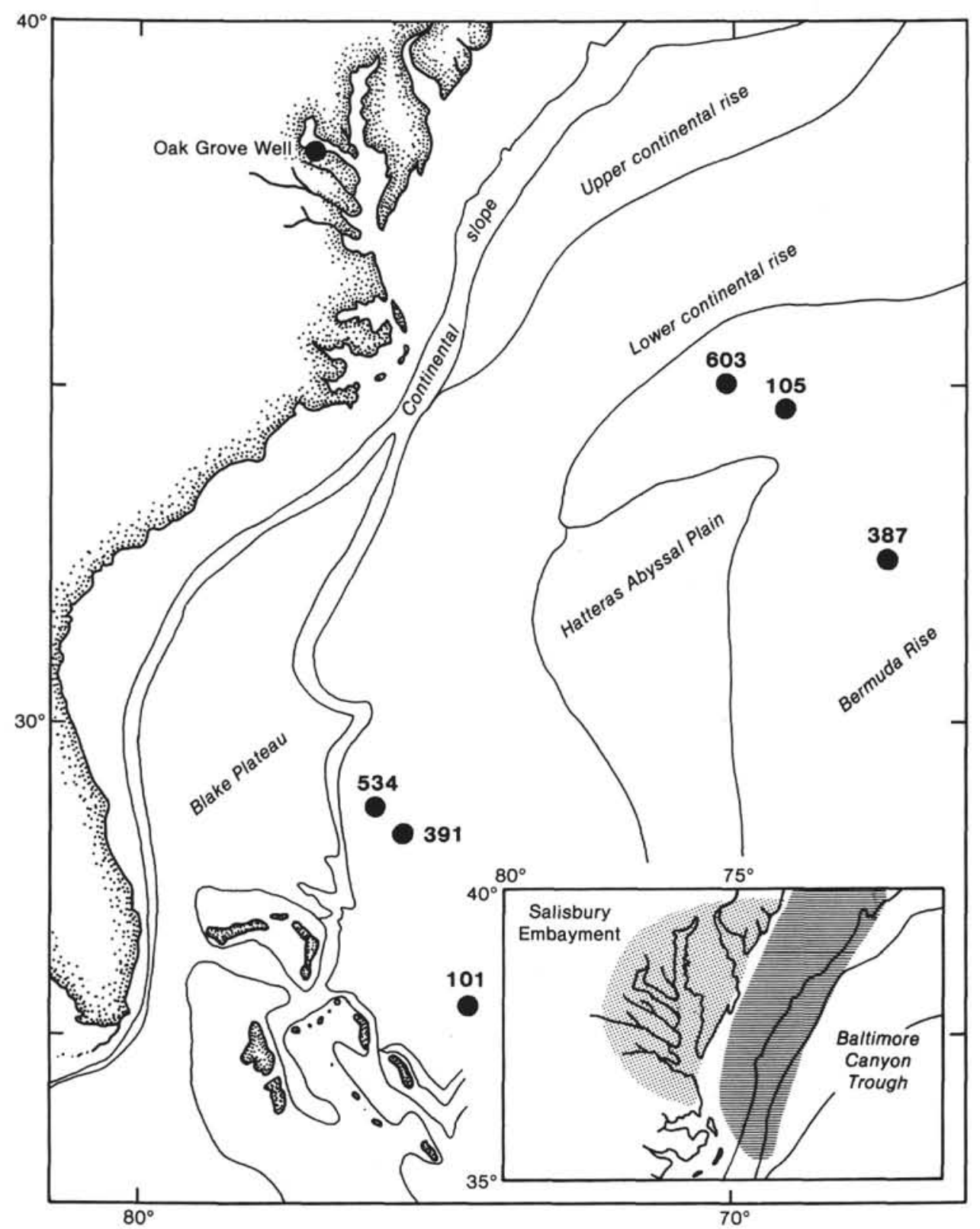

Figure 1. Location of borehole, DSDP sites, and structural elements in the study area. Insert shows outline of Salisbury Embayment and Baltimore Canyon Trough.

pelagic realm. Maldonado and Stanley (1981) found no correlation between clay mineral patterns in sediment from the southeast Levantine Sea and climatic fluctuations in the Mediterranean area during the last 23,000 yr. They concluded that depositional processes, not changes in climate, controlled clay mineral distribution in the sediment from that area. Smectite, usually trapped in prodelta mud, is brought to deeper depositional sites during periods of turbiditic deposition. Illite, transported by deep currents from the northwest, is the dominant clay type when hemipelagic deposition dominates the area. Carson and Arcaro (1983) also found a strong relationship between depositional process and clay mineral suite in deep-sea sediment, concluding that mode of transport, as opposed to climate, determined clay mineralogy of these deep-sea sediments. This type of depositional con- trol is also suggested by the work of Chamley (1979), Chamley and Robert (1982), and Chamley et al. (1983) for clay mineral suites of the western North Atlantic. They have proposed that "illitic events" correspond to the recurrence of erosion on the North American landmass. They attribute this to morphological rejuvenation of the continental margins, possibly caused by "aperiodic tectonic modifications." The sediments deposited during these events have high sedimentation rates and abundant resedimentation structures (Chamley et al., 1983).

The purpose of this study is to provide a preliminary analysis of the clay mineralogy of the Lower Cretaceous turbidite sequence at Site 603, which is the result of more direct marginal sediment input to the North American Basin. Forty-three samples from coarse-grained turbi- 

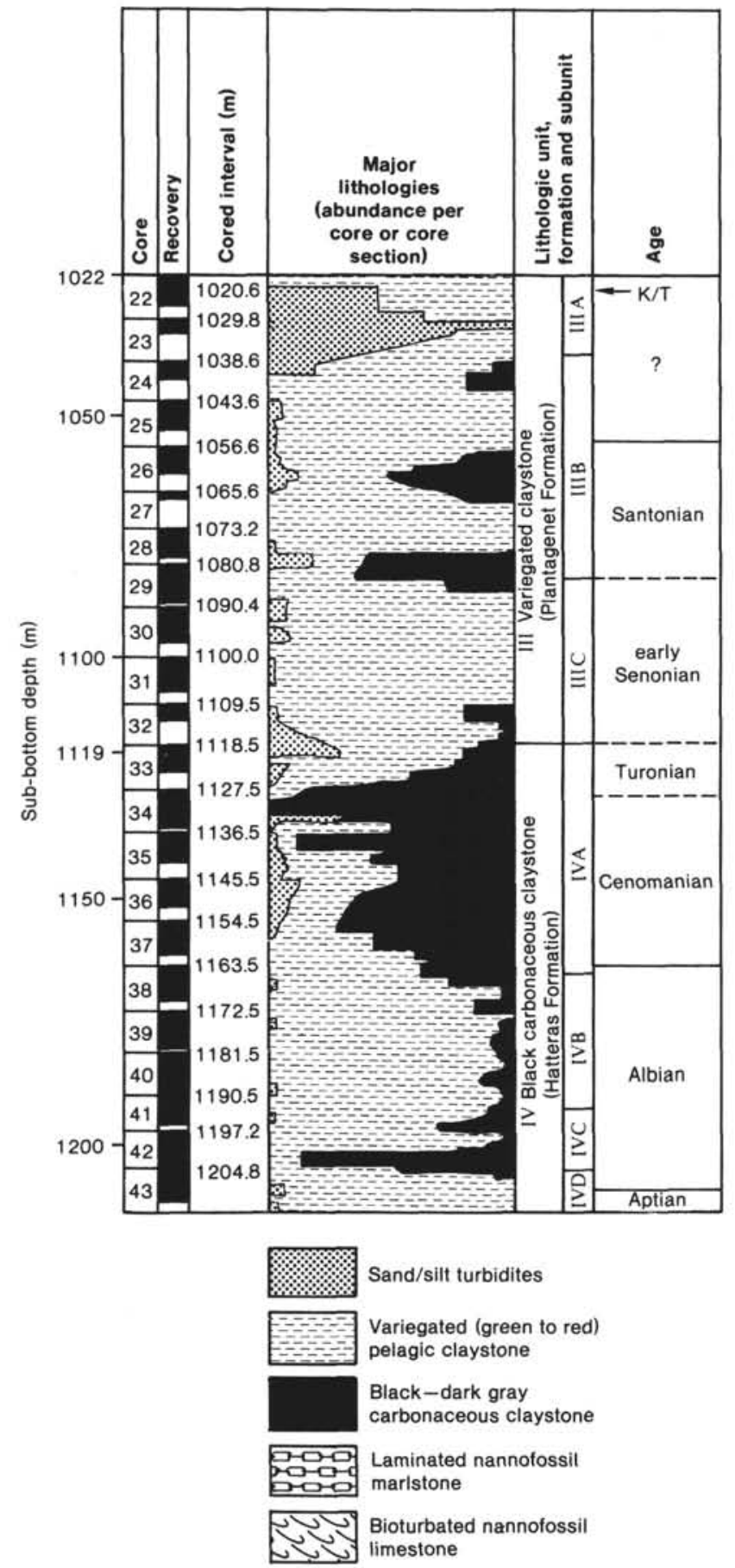

Figure 2. Columnar section of the Cretaceous interval of Hole 603B.

dites are examined by X-ray diffraction analysis in this study.

\section{PREVIOUS WORK IN THE STUDY AREA}

\section{North American Basin}

Possible redeposited sediments in the Blake-Bahama Formation were recovered at DSDP Site 101 (Fig. 1).

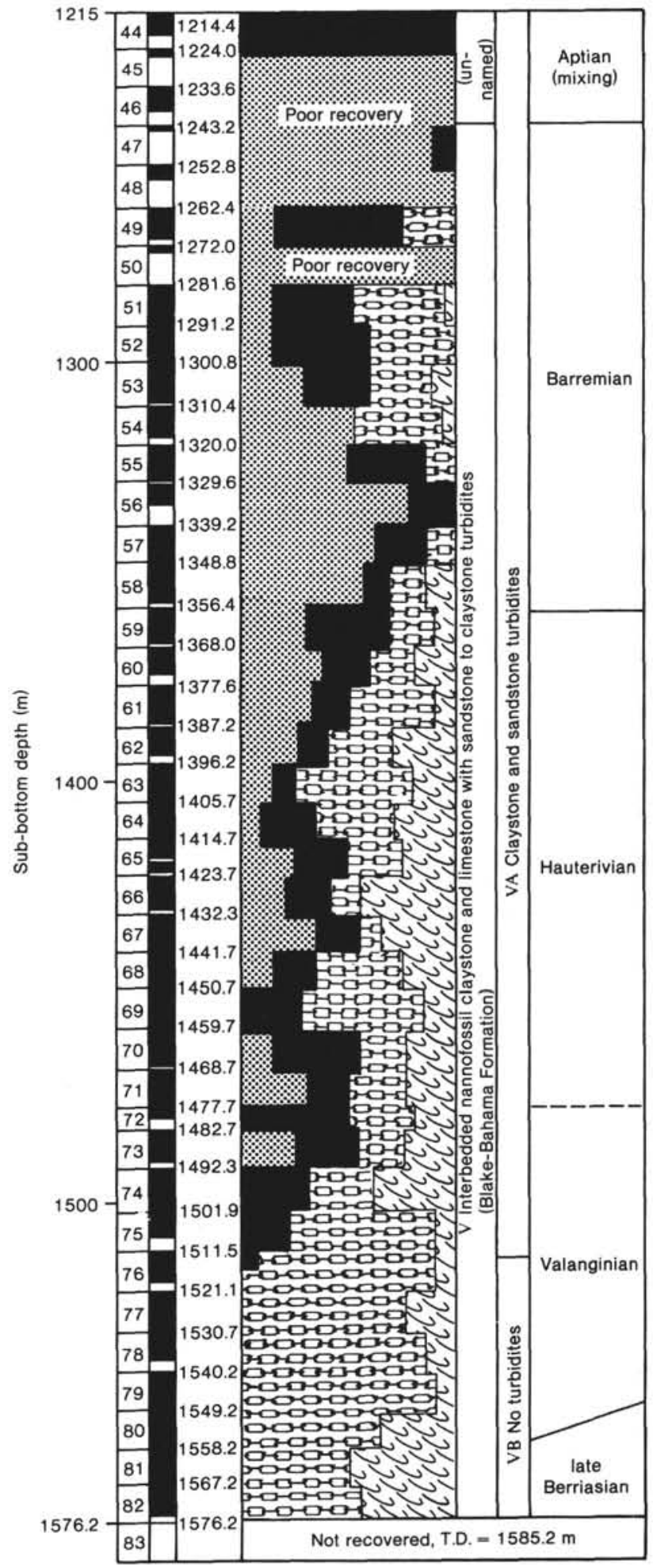

Thin interbeds of thinly laminated, dark gray clays were recovered in Cores 101-9A and -10A (Shipboard Scientific Party, 1972). X-ray analysis of the enclosing limestones reveals that mica is approximately twice as abundant as montmorillonite (Zemmels et al., 1972). At Site 105 (Fig. 1), the $<2-\mu \mathrm{m}$ fraction of Blake-Bahama Formation sediment is dominated by smectite, and mica occurs in smaller amounts (Zemmels et al., 1972, fig. 18). 


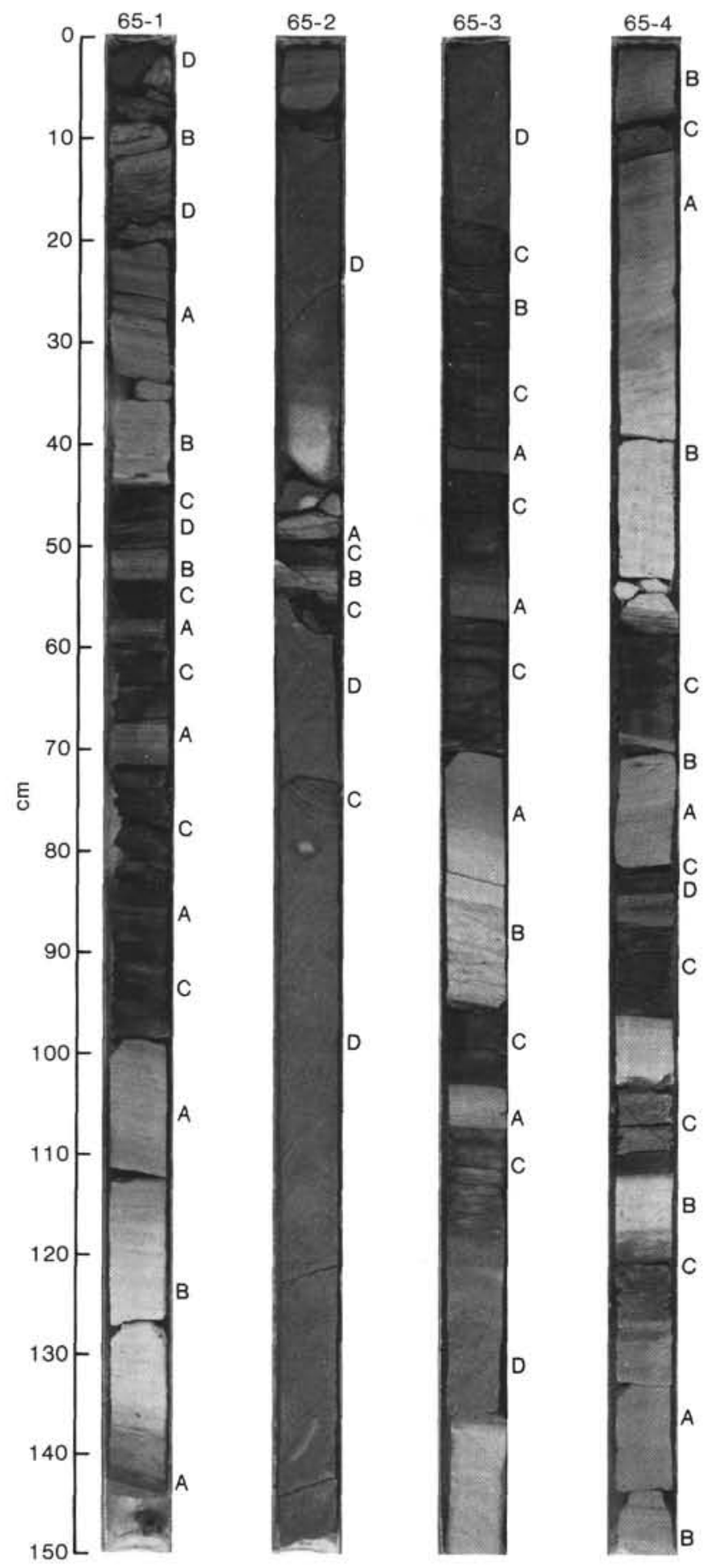

Figure 3. Core 603B-65 (1414.7-1423.7 m) from lithostratigraphic Unit VA (Blake-Bahama Formation, Valanginian-Aptian). A. Shows gray laminated marlstone. B. Indicates white bioturbated limestone cycles, interrupted by black carbonaceous claystone turbidites (C). and terrigenous sandstone turbidites (D). The sandstone bed spanning sections 603B-65-2 and 605B-65-3 is $90 \mathrm{~cm}$ thick (van Hinte et al., 1985).

No other minerals were detected except for small amounts of clinoptilolite in two samples. Although slump structures are evident in the Blake-Bahama Formation at this site, there is no indication that they are related to turbidite emplacement (Lancelot et al., 1972). No interbeds of claystone were reported in the Blake-Bahama Formation at DSDP Site 105. Chamley (1979) found an increase in illite level from less than $5 \%$ to a maximum of $15 \%$ in lower Barremian to lower Aptian (Core 105-17) and in Valanginian-Hauterivian (Cores 105-19 to -20) samples. These intervals also have an increase in mixedlayer clay and chlorite. At DSDP Site 387, the Blake-Bahama Formation (local lithostratigraphic Unit 7) contains a few minor interbeds of calcareous claystone (Shipboard Scientific Party, 1979), which are dominated by illite (85-100\%) (Koch and Rothe, 1979). Only one sample contains kaolinite (4\%, Sample 397-49-5, 111-113 $\mathrm{cm}$ ) and is early Barremian to late Hauterivian in age. Terrigenous and calcareous redeposited sediments were recovered in the Neocomian section (local lithostratigraphic Unit 4A) from DSDP Hole 391C (Fig. 1). The mineralogy of claystones in this interval was determined without removal of carbonate. Mica level varies from 0 to $17 \%$ (average of 29 samples: $1.7 \%$ ), montmorillonite level varies from 0 to $18 \%$ (average: $2.4 \%$ ), and kaolinite level varies from 0 to $3 \%$ (average: less than $1 \%$ ). In some samples mica is the dominant clay mineral, whereas montmorillonite dominates the suite of other samples. The clay mineralogy of Blake-Bahama sediment at DSDP Site 534 is dominated by smectite $(80-90 \%)$, with smaller amounts of illite (5-10\%), and usually less than $10 \%$ each of chlorite, kaolinite, and mixed-layer clays (Chamley et al., 1983). Again, certain intervals contain notable increases in illite level, often accompanied by increases in chlorite, irregular mixed-layer clay, quartz, and feldspar levels. For Lower Cretaceous sediment, the intervals occur during lower and upper Berriasian, and during upper Barremian to lower Aptian. These "illitic events" recur in the Blake-Bahama Basin through the Jurassic and Cretaceous and appear to be synchronous at various DSDP sites from Legs 11, 44, 76, and 77 (Chamley et al., 1983).

\section{Central Atlantic Coastal Plain and Continental Shelf}

Lower Cretaceous strata from the mid-Atlantic coastal plain of North America are classified as the Potomac Group, which can be divided in some places into the underlying Patuxent Formation and the overlying Patapsco Formation. These units were deposited by an extensive fluviodeltaic system that filled the Salisbury Embayment (Fig. 1) during the Cretaceous (e.g., Glaser, 1969). For a more detailed discussion of the lithostratigraphy of the Potomac Group, see Holmes et al. (this volume). The clay mineralogy of mid-Atlantic coastal plain nonmarine Cretaceous deposits, such as the Potomac Group, are dominated by kaolinite and have variable amounts of illite and no or very little montmorillonite (Groot and Glass, 1960; Knechtel et al., 1961). In western shore Maryland, clay mineral suites may be dominated by kaolinite or illite or a combination of both. Montmorillonite and chlorite were not detected in nonmarine sediment (Knechtel et al., 1961). Mixed-layer clays were usually subordinate (less than $15 \%$ ) but in a few samples composed up to $40 \%$ of the clay mineral suite. Reinhardt et al. (1980) conducted a sedimentologic analysis of core material recovered at Oak Grove, Virginia (Fig. 1), near the south- 
ern limit of the Salisbury Embayment. They reported that the clay minerals in clayey beds of the lower Potomac Group are mostly highly expandable mixed-layer illite/smectites. In sandy beds and in sand/clay laminations, kaolinite was the dominant interstitial clay mineral. In one interval, dated as Barremian to Albian, illite made up 40 to $80 \%$ of the clay mineral suite. Clay composition of the upper Potomac Group was similar to that of the lower, although clay type was not compared to lithology in that interval. Most samples from the upper Potomac Group had mixtures of kaolinite and highly expandable illite/smectite.

\section{MATERIALS AND METHODS}

\section{Lithostratigraphy}

In Hole 603B, local lithostratigraphic Unit V consists of an unnamed, $30-\mathrm{m}$ unconsolidated sand unit overlying $230 \mathrm{~m}$ of upper Berriasian-Aptian sandstone to claystone turbidites, interbedded with nannofossil marlstone and limestone. This lithostratigraphic unit is essentially equivalent to the Blake-Bahama Formation of Jansa et al. (1979). It is distinguished from the overlying lithostratigraphic Unit IV by the presence of abundant calcareous nannofossils and is divided into two subunits based on the presence or absence of turbidites. Subunit VA, which is the focus of this study, includes the upper $30 \mathrm{~m}$ of unconsolidated sand, and claystone, siltstone, and sandstone turbidites and debris flows. There are two types of turbidites: siltstone-sandstone and organic matter-rich claystone. The presence of intermediate types and complete sandstone- to claystone-graded sequences indicates that the two textural types may be related. Subunit VB is composed exclusively of in situ pelagic carbonates and is not examined in this study.

Organic-rich claystone turbidites (facies $\mathrm{D}_{3}$ of Sarti and von Rad, this volume) first appear in upper Valanginian sediment (Section 603B76-1, Fig. 2) and continue to the top of local lithostratigraphic Unit V (Section 603B-44-1). They range in thickness from a few to $80 \mathrm{~cm}$, average 20 to $40 \mathrm{~cm}$ thick, and generally decrease in thickness upcore. They have a high silt content, may be massive or faintly laminated, and are identical to the top layers of most sandstone turbidites, corresponding to Bouma division $T_{e}$ (Sarti and von Rad, this volume). Siltand sandstone turbidites first appear in the upper Valanginian (Section 603-73-4), reach a peak in the Barremian (Core 603-56), and culminate with the emplacement of a massive, poorly consolidated sand unit that spans the Barremian/Aptian boundary (Cores 603-48 to -45). Coarse, loose sand with shallow-water shell fragments, highly disturbed by drilling, constitutes nearly all of the sediment recovered from Cores 603B- 45 and -46 . Below Core 48 , individual turbidites range up to $2 \mathrm{~m}$ in thickness and are dominated by subangular quartz with abundant feldspar, mica, heavy minerals, opaques, wood fragments (locally up to $20 \%$ ), glauconite, and shallow-water bioclastics. Most sand units are poorly cemented and friable, except where the matrix has been replaced by calcite (Prezbindowski and Pittman, this volume) (for example, in Fig. 3, whitish material in Section 603B-65-2 between 36 and 43 $\mathrm{cm}$ is calcite-cemented). These turbidites exhibit the entire range of Bouma divisions, but basal sequences $\left(T_{a}\right.$ to $T_{c}$ ) are dominant (Site 603 Site chapter, this volume). Apparently, Hole 603B intersected a complex of one or more deep-sea fans that perhaps form part of an apron of clastic-rich sediment of this age along the lower continental margin of eastern North America (van Hinte et al., 1984).

\section{Procedures}

Samples were wet-sieved through a $62.5-\mu \mathrm{m}$ sieve to remove sand, and the excess water in the mud portion evaporated to a slurry. The weight of sand was determined and sand:mud ratios calculated (Table 1). The mud fraction was treated twice with $1 \mathrm{~N} \mathrm{HCl}$ to remove carbonate, then neutralized and $\mathrm{Na}$-saturated with $1 \mathrm{~N} \mathrm{NaOH}$ (Jackson, 1969) and washed by centrifugation until the supernatant was relatively free of dissolved organic matter. Two aliquots of the $<2-\mu \mathrm{m}$ fraction were withdrawn according to standard procedures (using Stokes' Law) and mounted onto glass slides using the filter-membrane peel technique of Drever as modified by Pollastro (1982). X-ray analyses of the oriented mounts were conducted on the University of Nebraska's GE diffractometer, using stepwise $\mathrm{CuK} \alpha$ radiation, a 0.00035-in.-thick Ni filter, and $1^{\circ}$ focusing slits, operated by an IBM Series 1 minicomputer and IBM Event Driven Executive software. Step increments were $0.05^{\circ} 2 \theta$, and each step counted for one second. One of the $<2-\mu \mathrm{m}$ mounts was $X$-rayed untreated from 2.0 to $40.0^{\circ} 2 \theta$ and again after glycolation from 2.0 to $15.0^{\circ} 2 \theta$. The other $<2-\mu \mathrm{m}$ mount was heated to $300^{\circ} \mathrm{C}$ and X-rayed from 2.0 to $15.0^{\circ} 2 \theta$.

Mineral identification was as follows: smectite-17- $\AA$ peak after glycolation; chlorite was not detected; kaolinite-7-Å peak after all treatments; illite-10- $\AA$ peak after all treatments; mixed-layer clay$<17$ - to $>9.90-\AA$ peak after glycolation.

Clay mineral abundances were approximated from the results of the glycolated XRD analyses according to Biscaye's (1965) peak ratio method using computer-determined peak counts (heights). The method used here was checked by preparing various mixes (by weight) of American Petroleum Institute clay mineral standards. These were mixed into pastes with distilled water and smeared onto glass slides to produce oriented mounts. Mineral abundances calculated from computer-iterated peak heights agreed with theoretical abundances to within \pm $10 \%$, if illite counts were multiplied by 2.5 instead of Biscaye's recommended 2.0. The results reported in Table 1 were calculated using the weighting factors of 0.5 for smectite, 1.0 for kaolinite, and 2.5 for illite. Percentage of expandability was calculated from the "saddle" to $17-\AA$ peak ratio using the graphic method of Rettke (1981) and assuming an illite to illite/smectite ratio of 1:1. It should be borne in mind that any attempt at quantification of clay mineralogy from X-ray diffractograms is semiquantitative at best, because of variations in diffractometers, degree or orientation of minerals, and other factors such as mineral chemistry and mineralogic imperfections. The results obtained here were repeatable to within $\pm 10 \%$. Although absolute amounts may differ if the samples were analyzed on different diffractometers, the variations upcore should be consistent.

Statistics were calculated using Statsoft STATS-2 statistical package. This program was used to calculate means, standard deviation, correlation coefficients (stated as " $r$ " values in the text), t-tests, and confidence levels of t-tests. Confidence levels for correlations were taken from table Y of Rohlf and Sokal (1969) and are stated as " $C$ " values in the text.

\section{RESULTS}

A diffraction trace of the three diffraction runs for an "average" sample is given in Figure 4. Glycolation (Fig. 4B) resulted in a sharp 17-Å peak with no evidence of chlorite at 12 to $14 \AA$. Untreated 12 - to $14-\AA$ peaks disappeared after the sample was heated to $300^{\circ} \mathrm{C}$ for $1 \mathrm{hr}$., indicating that there was not enough chlorite in any of the samples to be detected by this diffractometer. The smectite present in these samples is highly expandable (Table 1), with expandability values ranging from 83 to $97 \%$. There is no indication of the presence of any regularly stratified mixed-layer clay (i.e., all glycolated diffraction traces had peaks at 10 and $17 \AA$, with no intermediate peaks). All expandable clay is treated here as highly expandable smectite. The only other minerals detected were illite and kaolinite.

Smectite is the most abundant mineral detected (Table 1), composing an average $50 \%$ of the suite, and ranging from $26 \%(603 \mathrm{~B}-49-3,97-99 \mathrm{~cm})$ to $70 \%$ (603B-71-1, $117-118 \mathrm{~cm}$ ). Illite makes up an average $34 \%$ of the suite, ranging from $13 \%(603 \mathrm{~B}-71-1,117-118 \mathrm{~cm})$ to $56 \%$ $(603 \mathrm{~B}-46-1,60 \mathrm{~cm})$. Kaolinite averages $15 \%$, and ranges from $7 \%(603 \mathrm{~B}-44-4,100-102 \mathrm{~cm})$ to $29 \%$ (603B-56-2, $133-135 \mathrm{~cm})$. In most samples smectite is the dominant clay mineral, but in samples from Cores 603B-67, -57, $56,-49,-48,-46$, and -44 , illite dominates.

Smectite levels increase significantly with increasing depth $(r=+0.486, C=99 \%$, Fig. 5). Illite levels significantly decrease with increasing depth $(r=-0.532$, $C=99 \%$, Fig. 5). Consequently, illite and smectite have 
Table 1. Proportions of clay minerals in $<2-\mu \mathrm{m}$ fraction, percent mud, and bed thickness of samples from lower Cretaceous fan, Hole 603B.

\begin{tabular}{|c|c|c|c|c|c|c|c|c|}
\hline $\begin{array}{c}\text { Sample } \\
\text { (Core-Section, } \\
\text { interval in } \mathrm{cm} \text { ) }\end{array}$ & $\begin{array}{l}\text { Sub-bottom } \\
\text { depth (m) }\end{array}$ & $\begin{array}{l}\text { Smc } \\
(\%)\end{array}$ & $\operatorname{lll}_{(\%)}$ & $\begin{array}{l}\text { Kao } \\
(\%)\end{array}$ & $\begin{array}{l}\operatorname{EXP} \\
(\%)\end{array}$ & $\begin{array}{l}\text { Mud } \\
(\%)\end{array}$ & $\begin{array}{l}\text { Textural } \\
\text { class }^{\mathrm{a}}\end{array}$ & $\begin{array}{c}\text { Bed } \\
\text { thickness (cm) }\end{array}$ \\
\hline $44-1,18-19$ & 1214.6 & 30 & 54 & 17 & 84 & 99 & M & 20 \\
\hline $44-4,100-102$ & 1215.4 & 53 & 40 & 7 & 89 & 90 & M & NA \\
\hline $45-1,70-72$ & 1224.7 & 54 & 34 & 13 & 93 & 98 & M & NA \\
\hline $46-1,60$ & 1234.2 & 33 & 56 & 11 & 83 & 99 & M & NA \\
\hline $47-1,49-56$ & 1243.7 & 47 & 34 & 18.5 & 90 & 36 & MS & NA \\
\hline $48-2,100-102$ & 1254.8 & 34 & 48 & 18 & 84 & 58 & SM & NA \\
\hline $49-1,40-42$ & 1262.8 & 30 & 44 & 26 & 88 & 22 & MS & 100 \\
\hline $49-1,94-96$ & 1263.3 & 34 & 44 & 22 & 88 & 44 & MS & 100 \\
\hline $49-3,97-99$ & 1266.4 & 26 & 49 & 24 & 84 & 99 & $\mathrm{M}$ & 7 \\
\hline $50-1,113-114$ & 1273.1 & 54 & 33 & 13 & 96 & 79 & SM & 30 \\
\hline $51-1,87-88$ & 1282.4 & 57 & 30 & 13 & 96 & 94 & M & 13 \\
\hline $51-5,133-135$ & 1288.9 & 59 & 33 & 8 & 94 & 99 & M & 39 \\
\hline $51-5,135-137$ & 1289.0 & 43 & 37 & 20 & 94 & 99 & $\mathrm{M}$ & 16 \\
\hline $52-5,107-109$ & 1298.3 & 52 & 40 & 9 & 96 & 80 & SM & 110 \\
\hline $53-4,66-68$ & 1306.0 & 58 & 33 & 9 & 95 & 99 & M & 38 \\
\hline $54-4,55-56$ & 1315.4 & 69 & 19 & 12 & 90 & 46 & MS & 80 \\
\hline $55-2,73-74$ & 1322.2 & 65 & 23 & 11 & 94 & 89 & SM & 30 \\
\hline $56-2,133-135$ & 1332.4 & 30 & 41 & 29 & 90 & 39 & MS & 28 \\
\hline $57-1,36-37$ & 1339.5 & 34 & 52 & 14 & 90 & NA & NA & 10 \\
\hline $57-3,59-61$ & 1342.7 & 49 & 29 & 23 & 91 & 47 & MS & 95 \\
\hline $57-4,79-81$ & 1344.5 & 40 & 46 & 14 & 88 & 85 & SM & 22 \\
\hline $57-4,132-133$ & 1345.0 & 51.5 & 30.5 & 18.5 & 88 & 38 & MS & 95 \\
\hline $57-5,37-38$ & 1345.5 & 61 & 25 & 14 & 90 & 33 & MS & 95 \\
\hline $57-5,98-100$ & 1346.1 & 43 & 42 & 15 & 91 & 54 & SM & 82 \\
\hline $57-5,142-144$ & 1346.4 & 52 & 34 & 14 & 92 & 81 & SM & 7 \\
\hline $57-6,26-27$ & 1346.9 & 39 & 39 & 22 & 91 & 61 & SM & 58 \\
\hline $57-6,112-113$ & 1347.7 & 41 & 35 & 24 & 93 & 42 & MS & 35 \\
\hline $58-1,50-51$ & 1349.3 & 59 & 31 & 10.5 & 94 & 38 & MS & 23 \\
\hline $58-2,38-39$ & 1350.6 & 47 & 32.5 & 20 & 94 & 25 & MS & 38 \\
\hline $58-2,71-72$ & 1350.9 & 54 & 34 & 12 & 94 & 65 & SM & 80 \\
\hline $59-1,104-106$ & 1359.4 & 63 & 26 & 10 & 94 & NA & NA & 37 \\
\hline $60-2,97-99$ & 1369.9 & 65 & 14 & 21 & 94 & 31 & MS & 91 \\
\hline $60-3,100-102$ & 1370.6 & 49.5 & 38 & 12.5 & 94 & 36 & MS & 16 \\
\hline $62-2,113-114$ & 1388.8 & 63 & 29 & 8 & 94 & 60 & SM & 19 \\
\hline $63-7,16-17$ & 1405.3 & 68 & 15 & 17 & 94 & 39 & MS & 83 \\
\hline $65-2,86-89$ & 1417.0 & 43.5 & 40 & 16.5 & 89 & 45 & MS & 90 \\
\hline $66-5,23-24$ & 1429.9 & 65 & 26 & 9 & 96 & 31 & MS & 44 \\
\hline $67-1,107-110$ & 1433.8 & 42 & 46 & 12 & 94 & 98 & M & 34 \\
\hline $70-2,28-29$ & 1461.4 & 56 & 28 & 15 & 93 & 87 & SM & 43 \\
\hline $71-1,117-118$ & 1468.8 & 70 & 13 & 18 & 97 & 40 & MS & 150 \\
\hline $71-3,23,24$ & 1471.9 & 65.5 & 24.5 & 10.5 & 97 & 58 & SM & 18 \\
\hline $71-3,116-117$ & 1472.8 & 68 & 22 & 9 & 96 & 76 & MS & 112 \\
\hline 73-2, 93-94 & 1486.6 & 53 & 30 & 16 & 96 & 76 & MS & 20 \\
\hline Average & & 50.47 & 34.27 & 15.26 & 91.91 & 63.78 & & 52.84 \\
\hline Std dev & & 12.31 & 10.25 & 5.35 & 3.68 & 25.72 & & 37.05 \\
\hline Min. & 1214.6 & 26 & 13 & 7 & 83 & 22 & & 7 \\
\hline Max. & 1486.6 & 70 & 56 & 29 & 97 & 99 & & 150 \\
\hline Range & 272 & 44 & 43 & 22 & 14 & 77 & & 143 \\
\hline $\mathrm{N}$ & 43 & 43 & 43 & 43 & 43 & 41 & & 38 \\
\hline
\end{tabular}

Note: $\mathrm{NA}=$ not available; Std dev $=$ standard deviation; $\mathbf{N}=$ number; $\mathrm{Smc}=$ smectite, $\mathrm{Ill}=$ illite, Kao $=$ kaolinite, $\operatorname{Exp}=$ expandability.

${ }^{\mathrm{a}} \mathrm{MS}=$ muddy sand; $\mathrm{SM}=$ sandy mud; $\mathrm{M}=$ mud.

a significant, negative correlation $(r=-0.903, C=$ $99 \%$ ). The fact that illite content decreases and smectite content increases downcore indicates that little smectiteto-illite conversion has taken place in this sediment. In addition, smectite expandability increases with increasing depth $(\mathrm{r}=+0.574, \mathrm{C}=99 \%)$. Thus diagenesis may be assumed to have had little or no effect on the clay mineralogy of Lower Cretaceous sediment at this site. When the clay proportions are grouped according to age of the sediment (Table 2), smectite content clearly decreases upcore whereas illite content increases. The smectite level in Aptian and Barremian sediment is significantly different from that in Hauterivian and Valanginian sediment $(C=99 \%)$. The illite content of sediment from each age group is significantly different from all other age groups ( $C=95 \%$ or greater). Kaolinite levels show no relationship with depth $(r=-0.122$, Fig. 5). When grouped according to age (Table 2), kaolinite content has a tendency to increase in Barremian sediment $(C \geq 80 \%)$. Kaolinite level is negatively correlated with smectite level $(r=-0.574, C=99 \%)$ but is not related to illite level $(r=+0.169)$. In this sediment, kaolinite and illite behave independently of one another.

The thickness of the beds sampled for this study range from 7 to $150 \mathrm{~cm}$ (Table 1). Each clay type was compared to bed thickness to determine if clay-sized material in this sediment was sorted in different facies of the fan. Thicker beds are representative of facies receiving more direct sediment input, such as channel facies (e.g., Mutti and Ricci Lucchi, 1978; facies A, B, and C), and 

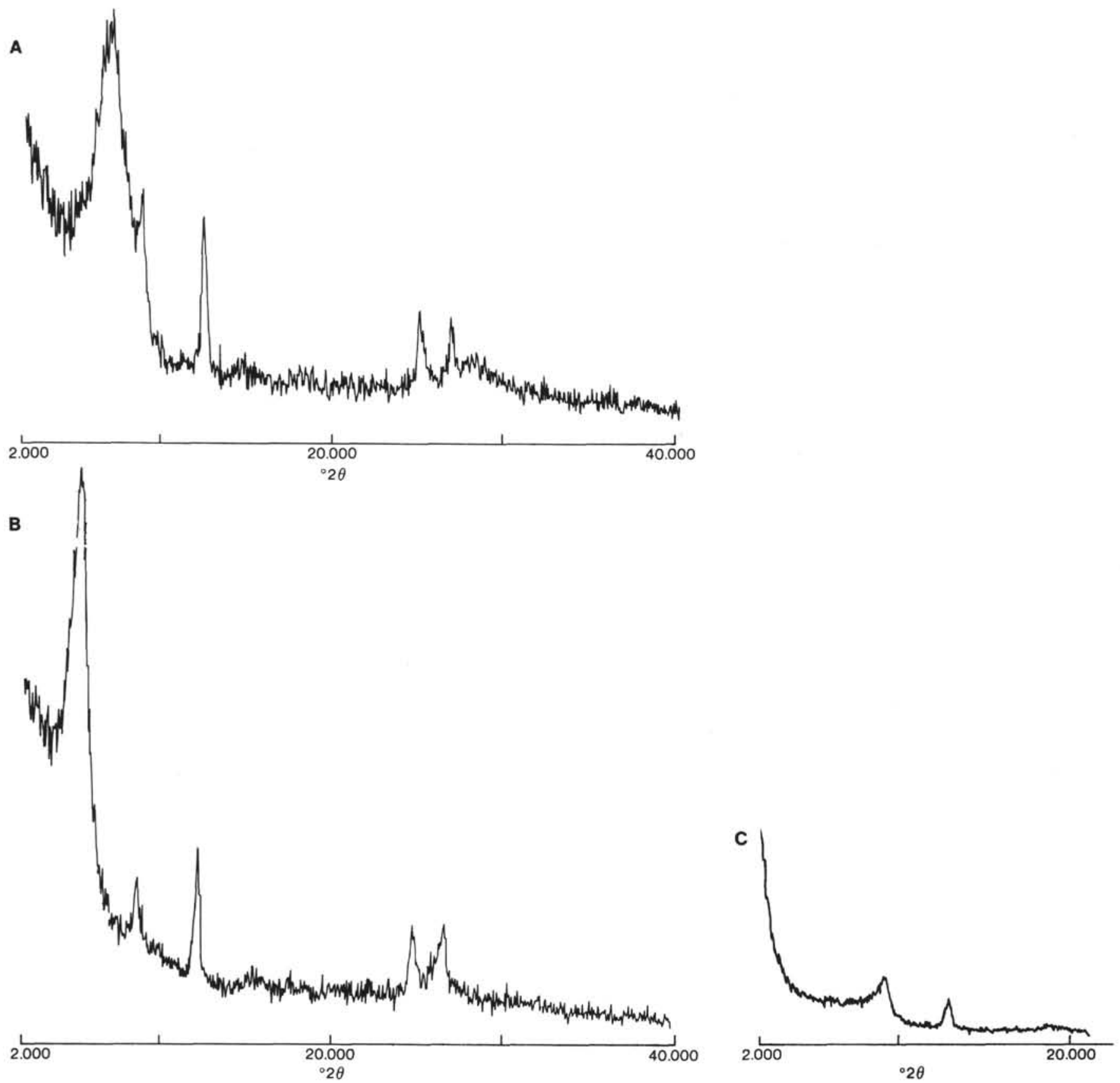

Figure 4. X-ray diffractogram of 3 runs of a $<2-\mu \mathrm{m}$ sample, (603B-57-6, 112-113 cm). A. Untreated sample; B. Glycolated sample; C. Sample heated to $300^{\circ} \mathrm{C}$.

in this sediment thicker beds have a tendency to have a higher proportion of sand (for percent mud vs. bed thickness, $r=-0.361, C=95 \%)$. Smectite levels increase with increasing bed thickness $(r=+0.429, C=95 \%)$. Illite level decreases with increasing bed thickness $(r=$ $-0.514, C=99 \%$ ). Kaolinite content is not related to bed thickness $(r=+0.030)$.

Smectite content shows no relationship with the amount of mud in a sample $(r=-0.121)$, whereas illite content tends to increase with increasing amounts of mud $(r=+0.361, C=90 \%)$. Thus illite shows a tendency to be more abundant in thinner-bedded units with a higher mud content. Kaolinite content decreases with increas- ing percent mud $(r=-0.408, C=99 \%)$. The proportion of mud in each sample ranges from 22 to $99 \%$ (Table 1). These values correspond to muddy sand (10-50\% mud), sandy mud (51-90\% mud), and mud ( $>90 \%$ mud). Seventeen samples are muddy sand, with 22 to $47 \%$ mud, and bed thickness ranging from 16 to $150 \mathrm{~cm}$ (average: $73 \mathrm{~cm}$ ). Most of these samples are dominated by smectite. Smectite and illite levels are negatively correlated ( $r$ $=-0.924, C=99 \%$ ) in muddy sand, as are smectite and kaolinite levels $(r=-0.702, C=99 \%)$. Kaolinite and illite are not significantly correlated in muddy sand $(r=+0.378)$. Smectite levels increase with increasing depth $(r=+0.586, C=95 \%)$, whereas illite levels de- 


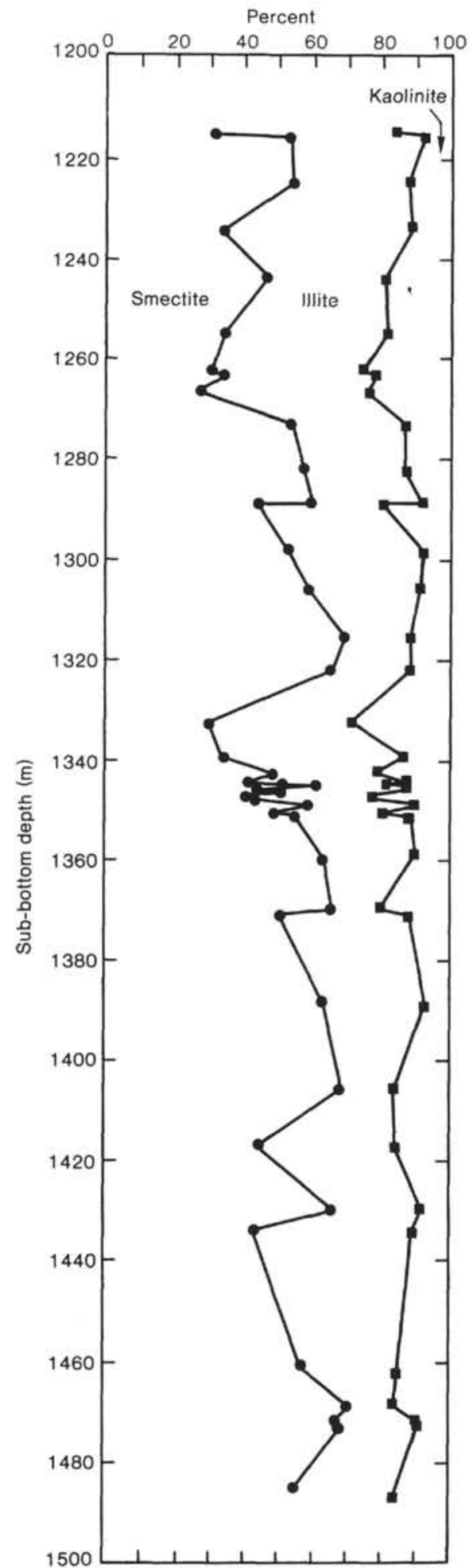

Figure 5. Vertical distribution of smectite and illite, and kaolinite, $<2-\mu \mathrm{m}$ fraction, Hole 603B.

crease $(r=-0.547, C=95 \%)$. The kaolinite level does not change regularly with depth $(r=-0.384)$. None of the clay types increase or decrease with changing percentage of mud within the muddy sand subset. Illite levels decrease with increasing bed thickness $(r=-0.644$,
Table 2. Mean proportions of clay minerals by stage, Hole 603B.

\begin{tabular}{llllllll}
\hline Stage & & $\begin{array}{c}\text { Smc } \\
(\%)\end{array}$ & $\begin{array}{c}\text { III } \\
(\%)\end{array}$ & $\begin{array}{c}\text { Kao } \\
(\%)\end{array}$ & $\begin{array}{c}\text { Exp } \\
(\%)\end{array}$ & $\begin{array}{c}\text { Mud } \\
(\%)\end{array}$ & $\begin{array}{c}\text { Bed } \\
\text { thickness }(\mathrm{cm})\end{array}$ \\
\hline \multirow{4}{*}{ Aptian } & Average & 42.5 & 46 & 12 & 87.25 & 96.5 & 20 \\
& Std dev & 11.05 & 9.273 & 3.605 & 4.0233 & 3.7749 & 0 \\
& $\mathrm{~N}$ & 4 & 4 & 4 & 4 & 4 & 1 \\
& Average & 47.25 & 36.07 & 16.67 & 91.346 & 62.08 & 51.29 \\
& Atd dev & 11.41 & 7.979 & 5.680 & 3.3159 & 25.451 & 34.62 \\
& $\mathrm{~N}$ & 26 & 26 & 26 & 26 & 25 & 24 \\
\multirow{5}{*}{ Hauterivian } & Average & 57.22 & 29.11 & 13.44 & 93.555 & 53.375 & 50.77 \\
& Std dev & 9.339 & 10.17 & 4.023 & 1.7708 & 24.356 & 27.87 \\
& $\mathrm{~N}$ & 9 & 9 & 9 & 9 & 8 & 9 \\
& Average & 64.12 & 22.37 & 13.37 & 96.5 & 62.5 & 75 \\
& Std dev & 6.617 & 6.137 & 3.731 & 0.5 & 14.924 & 57.59 \\
& $\mathrm{~N}$ & 4 & 4 & 4 & 4 & 4 & 4 \\
\hline
\end{tabular}

Note: $\mathrm{Smc}=$ smectite, $11 \mathrm{ll}=$ illite, $\mathrm{Kao}=$ kaolinite, Exp $=$ expandability; Std dev $=$ standard deviation; $\mathrm{N}=$ number.

$C=95 \%$ ), but smectite and kaolinite levels are not correlated with bed thickness in muddy sand.

Eighteen sandy mud samples contain 54 to $98 \%$ mud, and beds range in thickness from 7 to $112 \mathrm{~cm}$ (average: $45 \mathrm{~cm}$ ). Smectite tends to be the dominant mineral. Again, smectite and illite levels are negatively correlated $(r=$ $-0.922, C=99 \%$ ), as are smectite and kaolinite levels $(r=-0.706, C=99 \%)$; illite and kaolinite levels in sandy muds are not related $(r=+0.381)$. Only illite varies regularly with depth in sandy mud $(r=-0.560$, $C$ 95\%). Smectite $(r=-0.399)$ and kaolinite $(r=$ +0.035 ) levels have no correlation with depth in this sediment type. None of the clay mineral species varies significantly with changing bed thickness in sandy mud.

Six mud samples have $90 \%$ or more mud, and beds range from 7 to $39 \mathrm{~cm}$ thick (average: $24 \mathrm{~cm}$ ). Smectite and illite are present in approximately the same amounts (average: $42 \%$ smectite, $44 \%$ illite). Smectite and illite levels are again negatively correlated $(r=-0.891, C=$ $99 \%$ ), but the kaolinite level is not correlated to either the smectite $(r=-0.727)$ or illite $(r=+0.340)$ level. There is no relationship between any clay mineral and depth in mud samples. This indicates that the negative relationship between smectite and illite in these samples is not caused by their variation with depth. Smectite level increases with increasing bed thickness $(r=+0.862$, $C=95 \%$ ), and kaolinite level decreases with increasing bed thickness $(r=-0.995, C=99 \%)$. Illite level has no relationship with bed thickness $(r=-0.592)$ in mud from this core.

The average amounts of clay minerals in the three sediment types show significant differences (Table 3). Smectite levels are significantly $(C \geq 90 \%)$ lower in mud than in muddy sand or sandy mud. The smectite content of muddy sand and sandy mud is not significantly different. Illite levels are significantly $(C \geq 98 \%)$ higher in mud than in sandy mud or muddy sand. Sandy mud and muddy sand have similar amounts of illite. The levels of kaolinite are higher $(C \geq 86 \%)$ in muddy sand than in sandy mud or mud.

\section{DISCUSSION}

Although it is usually assumed that kaolinite and illite are terrigenous components of deep-sea sediment that behave in more or less the same way, the complete lack 
Table 3. Mean proportions of clay minerals in sediments by textural class, Hole 603B.

\begin{tabular}{ccccccc}
\hline $\begin{array}{c}\text { Textural } \\
\text { class }\end{array}$ & $\begin{array}{c}\text { Smc } \\
(\%)\end{array}$ & $\begin{array}{c}\text { III } \\
(\%)\end{array}$ & $\begin{array}{c}\text { Kao } \\
(\%)\end{array}$ & $\begin{array}{c}\text { Exp } \\
(\%)\end{array}$ & $\begin{array}{c}\text { Mud } \\
(\%)\end{array}$ & $\begin{array}{c}\text { Bed } \\
\text { thickness }(\mathrm{cm})\end{array}$ \\
\hline Muddy sand & & & & & & \\
Average & 51.74 & 30.06 & 18.32 & 91.76 & 37.18 & 72.69 \\
Std dev & 13.03 & 9.88 & 5.40 & 2.82 & 6.84 & 36.13 \\
Min. & 30 & 13 & 9 & 88 & 22 & 16 \\
Max. & 70 & 44 & 29 & 97 & 47 & 150 \\
N & 17 & 17 & 17 & 17 & 17 & 16 \\
& & & & & & \\
Sandy mud & & & & & & \\
Average & 52.47 & 34.58 & 12.86 & 93.00 & 77.17 & 45.2 \\
Std dev & 9.42 & 7.78 & 3.57 & 3.30 & 14.18 & 33.7 \\
Min. & 34 & 22 & 7 & 84 & 54 & 7 \\
Max. & 68 & 48 & 22 & 97 & 98 & 112 \\
N & 18 & 18 & 18 & 18 & 18 & 15 \\
& & & & & & \\
Mud & & & & & & \\
Average & 41.50 & 43.67 & 14.83 & 89.00 & 99.00 & 24 \\
Std dev & 13.07 & 9.66 & 5.93 & 5.35 & 0.00 & 12.6 \\
Min. & 26 & 33 & 8 & 83 & 99 & 7 \\
Max. & 59 & 56 & 24 & 95 & 99 & 39 \\
N & 6 & 6 & 6 & 6 & 6 & 5 \\
\hline
\end{tabular}

Note: See Table 2 for identification of abbreviations

of correlation between these two clay types, regardless of sand:mud ratio, indicates that they behave independently of one another in this sediment, which points to the fact that kaolinite and illite input to this sediment was somehow different. One explanation of this difference is that kaolinite and illite may have different sources, and the input of one clay type or the other represents a change in provenance for this sediment. For example, today on the east coast of North America, rivers that arise in the Piedmont province have clay mineral suites dominated by kaolinite, followed by vermiculite, illite, chlorite, and montmorillonite (Pevear, 1972). Small rivers that arise in the coastal plain have higher amounts of montmorillonite, but in either case, the river clay strongly reflects the mineralogy of soils in its watershed (Pevear, 1972). Thus it is possible that in the Early Cretaceous, different rivers, arising in and draining different provinces of the eastern North American continent, could have contributed sediment with kaolinite-dominated clay suites or illite-dominated clay suites. The kaolinite-rich river or rivers would have been particularly dominant in the Barremian, whereas the illite-rich river or rivers would have become increasingly important (as contributor of fine-grained sediment) from the Valanginian (almost no direct influence) through the Aptian.

The results of heavy mineral and textural analyses (Holmes et al., this volume) indicate the possibility of a separate, epidote-rich source that may represent a more upland-derived sediment. This source contributed to the Site 603 fan from the Hauterivian to Aptian, and became the dominant source in the late Barremian and Aptian. Illite level increases with increasing epidote level $(r=+0.496, C=95 \%)$. Illite may have been the dominant fine-grained mineral in an epidote-enriched fluvial system. A more upland source of illite could be Paleozoic sedimentary rock of the Appalachian province. The other source of coarse sediment at Site 603 appears to be enriched in zircon, apatite, and garnet (Holmes et al., this volume). Smectite level is positively correlated with that of apatite $(r=+0.689, C=99 \%)$ and has a tendency to increase with increasing garnet level $(r=$ $+0.467, C=93 \%$ ). Thus smectite could be the dominant fine-grained mineral in a zircon-apatite-garnet-enriched fluvial system. Kaolinite is not correlated with any of the heavy minerals. Future studies on this problem would be enhanced by a K-Ar date of the illite in this sediment. If the illite is largely Paleozoic in age, it would strongly support the hypotheses of Chamley (1979) that the eastern North American continent had extensive Vertisol development in the Early Cretaceous.

Another possibility is that the clay was sorted by size prior to redeposition. The results of several different studies, including those discussed previously (Carson and Arcaro, 1983; Maldonado and Stanley, 1981), indicate that clay-sized particles are sorted in coastal, shelf, and marine environments. Other studies supporting this contention include that of Brown et al. (1977), who found a landward increase in kaolinite level and a seaward increase in illite level in Pennsylvanian sediment from northern Missouri and southern Iowa, and Gibbs (1977), who studied the clay mineralogy of Recent sediment from the mouth of the Amazon River for a distance of $1400 \mathrm{~km}$ along the shelf. He found that montmorillonite levels increase with increasing distance from the river mouth whereas kaolinite and illite levels decrease. In addition, Holocene sediment of the eastern North American shelf is dominated by illite in the northern half (Hathaway, 1972) and by smectite in the southern half (Pevear, 1972). Doyle et al. (1979) reported that smectite dominates the clay mineral assemblages of Holocene slope sediment. They further note that a large amount of kaolinite in this sediment indicates that some estuarine bypassing of fine-grained sediment takes place. Another line of evidence to support this hypothesis is that in mid-Atlantic coastal plain sediment, nonmarine strata are dominated by kaolinite and sometimes illite; marine strata on the other hand are primarily dominated by illite and montmorillonite (Groot and Glass, 1960; Lonnie, 1982). This evidence provides an alternate explanation for why Lower Cretaceous North American Basin sediment is normally dominated by smectite, and why certain intervals have greater amounts of illite and kaolinite. Kaolinite is usually the larger particle and of a more equant shape, which enhances its settling velocity. Smectite is usually the smallest particle (Gibbs, 1977) and has a flaky or leaflike morphology that retards settling through a water column. Thus kaolinite tends to be deposited in continental and near-shore environments, illite tends to dominate in transitional environments, and smectite tends to be carried out to the deep sea. Weaver (1967) reported that Cretaceous shales in general appear to be low in kaolinite and also that kaolinite content always decreases from fluvial to open marine environments, whereas montmorillonite increases. Weaver concluded that for the Cretaceous, kaolinite and montmorillonite appear to have consistent environmental significance.

The higher illite and kaolinite levels encountered in this sequence correspond to intervals of maximum sand input and thus maximum turbidite activity. These in- 
clude samples from Cores 603B-67 (46\% illite), -60 (21\% kaolinite), -57 (up to $52 \%$ illite and up to $24 \%$ kaolinite), -56 (29\% kaolinite), -49 (44-49\% illite and $22-26 \%$ kaolinite), -46 ( $56 \%$ illite), and -44 (54\% illite). These may be intervals receiving more direct continental input, when fine-grained sediment bypassed the shelf and slope. Compared to the clay mineral suites of pelagic sediment at other DSDP localities in the North American Basin, the sediment of the deep-sea fan recovered at Site 603 is enriched in illite and kaolinite. Fan deposition at this locality would then correspond to one large "illitic event." As Chamley et al. (1983) pointed out, "illitic events" correspond to high sedimentation rates in the deep sea and occur in beds with abundant resedimentation structures. "Illitic events" probably correspond to intervals of turbiditic activity of the North American continental margin, or to some continental event that causes finegrained sediment to bypass the shelf and slope, such as flooding.

Yet another explanation for kaolinite-rich intervals in this sediment is eolian input. Lever and McCave (1983) concluded that clays have been supplied to the North Atlantic by wind blowing from the American and African continents since the Early Cretaceous.

The sand units in this sequence have an unusually high level of mud compared to other ancient turbidites (Sarti and von Rad, this volume). Sarti and von Rad (this volume) have given a new designation for this type of turbidite, "facies $\mathrm{C}_{\mathrm{SL}}$," and hypothesize that during downslope movement turbidity currents incorporated copious mud from the consumption of rip-up clasts. A preliminary examination of some of these rip-ups reveals that they are rich in calcareous nannofossils and low in terrigenous components. The absence of Nannoconus and Braarudosphaera in the clasts suggests that the mud accumulated away from continental influence (D.K. Watkins, personal communication, 1986), possibly from pelagic accumulation in deep-sea channels between turbidite flows. Sarti and von Rad (this volume) reported that the succession of turbidite flows at this locality was widely spaced in time, about one event every 30,000 to 60,000 yr. Pelagic sediment accumulation rates in the North American Basin during the Early Cretaceous are on the order of $0.25 \mathrm{~cm} / 1000$ yr. (e.g., Site 603 chapter, this volume). Rip-up clasts are generally less than $1.0 \mathrm{~cm}$ thick, so there is ample time for a layer of pelagic mud to have accumulated in slope and deep-sea channels between turbidity flows. This could explain why smectite content increases as bed thickness increases in this sediment.

The sediment exhibits differences according to the sand: mud ratio. Muddy sands are thicker-bedded. They are dominated by smectite, followed by illite, and have the highest levels of kaolinite for any of the three textural classes. Kaolinite is the coarsest clay in this sediment, as indicated by a preliminary analysis of X-ray diffractograms of 20 - and $40-\mu \mathrm{m}$ fractions. Kaolinite is present in these size classes in considerable amounts.

The muds show certain characteristics that distinguish them from sandy mud and muddy sand. Smectite levels are significantly lower in mud, and illite levels significantly higher. These two clays are present in roughly equal amounts. Habib (1982) has shown that the organic matter in Early Cretaceous "black clays" of the North Atlantic is largely terrigenous, and it would appear from these results that they contain a large component of probably terrigenous illite as well. Thus illite:smectite ratios of marine black shales may be useful in determining terrigenous versus marine influence, which could be helpful in petroleum exploration. The clay mineralogy of the muds is different enough from that of the muddy sand or sandy mud that it may have had a different mode of deposition. Robertson and Bliefnick (1983) proposed that fine-grained redeposited sediment recovered at Site 534 was supplied by the outer shelf and slope, whereas coarsegrained redeposited sediment came from inner-shelf, possibly outer-deltaic, environments. Such a scenario is likely for the turbidites recovered in this sequence.

\section{SUMMARY AND CONCLUSIONS}

The clay mineral suites of the Lower Cretaceous deepsea fan recovered at Site 603 are largely dominated by smectite, but there are significant exceptions where illite is dominant. These intervals occur at times of higher turbiditic activity (Cores 603B-67, $-57,-49,-48$, and 46). Other intervals have increased levels of kaolinite. These also correspond to times of high turbidite activity, but do not always occur when illite levels are increased. Kaolinite and illite may thus represent different sources of fine-grained sediment. However, kaolinite is not correlated with any heavy mineral, whereas smectite is correlated with apatite and garnet, and illite is correlated with epidote. Thus three fluvial systems may have contributed sediment to Site 603 during the Early Cretaceous, one dominated by smectite in the fine fraction, and garnet, apatite, and zircon in the coarse (heavy) fraction; another dominated by illite in the fine fraction, and epidote in the coarse (heavy) fraction; and a third dominated by kaolinite in the fine fraction, with an indeterminate coarse fraction. This seems unlikely. A more reasonable explanation is that clay-sized material is sorted by pericontinental processes prior to deposition. Smectite, the slowest of the clays to settle, normally is the dominant clay to escape to the deep sea. Illite would tend to accumulate in transitional environments. Kaolinite, the coarsest-grained and most rapid to settle of the clays, is normally deposited in continental or nearshore environments, because crystallites are larger (e.g., Gibbs, 1977).

There is some evidence from these data that some sorting of clay minerals occurs in turbidity currents. Kaolinite is more abundant in muddy sand; illite tends to be more abundant in thinner-bedded units and in mud. This may also reflect the different sizes of the clay minerals.

\section{ACKNOWLEDGMENTS}

The author wishes to thank Dennis S. Cassidy and S. W. Wise, Jr. of the FSU Antarctic Research Facility, and the University of Nebraska Geology Department for laboratory equipment and support, and to Robert B. Nelson for help with the diffractometer and software. David K. Watkins reviewed an early draft of the manuscript; Randall Hughes and David M. Patrick reviewed a later draft; their comments and suggestions have been most helpful. 


\section{REFERENCES}

Biscaye, P. E., 1965. Mineralogy and sedimentation of recent deep-sea clay in the Atlantic Ocean and adjacent seas and oceans. Geol. Soc. Am. Bull., 76:803-832.

Brown, L. F., Jr., Bailey, S. W., Cline, L. M., and Lister, J. S., 1977. Clay mineralogy in relation to deltaic sedimentation patterns of Desmonian cyclothems in Iowa-Missouri. Clays Clay Miner., 25: 171-186.

Carson, B., and Arcaro, N. P., 1983. Control of clay-mineral stratigraphy by selective transport in Late Pleistocene-Holocene sediments of northern Cascadia Basin-Juan de Fuca Abyssal Plain: implications for studies of clay-mineral provenance. J. Sed. Petrol., 53: 395-406.

Chamley, H., 1979. North Atlantic clay sedimentation and paleoenvironment since the Late Jurassic. In Talwani, M., Hay, W., and Ryan, W. B. F. (Eds.), Deep Drilling Results in the Atlantic Ocean: Continental Margins and Paleoenvironment: Washington, D.C. (Am. Geophys. Union), Maurice Ewing Ser., 3:342-361.

Chamley, H., Debrabant, P., Candillier, A. -M., and Foulon, J., 1983. Clay mineralogical and inorganic geochemical stratigraphy of BlakeBahama Basin, North Atlantic. In Sheridan, R. E., Gradstein, F. M., et al., Init. Repts. DSDP, 76: Washington (U.S. Govt. Printing Office), 437-451.

Chamley, H., and Robert, C., 1982. Paleoenvironmental significance of clay deposits in Atlantic black shales. In Schlanger, S. O., and Cita M. B. (Eds.), Nature and Origin of Cretaceous Carbon-rich Facies: London (Academic Press), pp. 101-112.

Doyle, L. J., Pilkey, O. H., Jr., and Woo, C. C., 1979. Sedimentation on the eastern United States continental slope. In Doyle, L. J., and Pilkey, O. H., Jr. (Eds.), Geology of Continental Slopes. Soc. Econ. Paleontol. Mineral. Spec. Publ., 27:119-129.

Flood, R. D., 1978. X-ray mineralogy of DSDP Legs 44 and 44A, western North Atlantic: lower continental rise hills, Blake Nose, and Blake-Bahama Basin. In Benson, W. E., Sheridan, R. E., et al., Init. Repts. DSDP, 44: Washington (U.S. Govt. Printing Office), 515-521.

Gibbs, R. J., 1977. Clay mineral segregation in the marine environment. J. Sed. Petrol., 47:237-243.

Glaser, J. D., 1969. Petrology and origin of Potomac and Magothy (Cretaceous) sediments, middle Atlantic Coastal Plain. Maryland Geol. Surv. Rept. Invest. No. 11.

Groot, J., and Glass, H. D., 1960. Some aspects of the mineralogy of the northern Atlantic Coastal Plain. In Swineford, A. (Ed.), Proc. Seventh Natl. Congress Clays and Clay Minerals: London (Pergamon Press), pp. 271-284.

Habib, D., 1982. Sedimentary supply origin of Cretaceous black shales. In Schlanger, S. O., and Cita, M. B. (Eds.), Nature and Origin of Cretaceous Carbon-rich Facies: London (Academic Press), pp. 113127.

Hathaway, J. C., 1972. Regional clay mineral facies in estuaries and continental margin of the United States east coast. Geol. Soc. Am. Mem., 133:293-316.

Hinte, J. E. van, Wise, S. W., Jr., et al., 1985. DSDP Site 603: first deep $(>1000 \mathrm{~m})$ penetration of the continental rise along the passive margin of eastern North America. Geology, 13:392-396.

Jackson, M. L., 1969. Soil chemical analysis-advanced course (2nd ed., 10th printing): Madison, WI (Published by the author), pp. 27-166.

Jansa, L. F., Enos, P., Tucholke, B. E., Gradstein, F. M., and Sheridan, R. E., 1979. Mesozoic-Cenozoic sedimentary formations of the North American Basin; western North Atlantic. In Talwani, M., Hay, W., and Ryan, W. B. F. (Eds.), Deep Drilling Results in the Atlantic Ocean: Continental Margins and Paleoenvironment: Washington, D.C. (Am. Geophys. Union), Maurice Ewing Ser. 3: $1-57$.
Knechtel, M. M., Hamlin, H. P., Hosterman, J. W., and Carroll, D., 1961. Physical properties of nonmarine Cretaceous clays in the Maryland Coastal Plain. Dept. Geology, Mines, Water Res. Bull. 23.

Koch, R., and Rothe, P., 1979. X-ray mineralogy studies-Leg 43. In Tucholke, B. E., Vogt, P. R., et al., Init. Repts. DSDP, 43: Washington (U.S. Govt. Printing Office), 1019-1042.

Lancelot, Y., Hathaway, J. C., and Hollister, C. D., 1972. Lithology of sediments from the western North Atlantic, Leg 11, Deep Sea Drilling Project. In Hollister, C. D., Ewing, J. I., et al., Init. Repts. DSDP, 11: Washington (U.S. Govt. Printing Office), 901-949.

Lever, A., and McCave, I. N., 1983. Eolian components in Cretaceous and Tertiary North Atlantic sediments. J. Sed. Petrol., 53:811-832.

Lonnie, T. P., 1982. Mineralogic and chemical comparison of marine, nonmarine, and transitional clay beds of south shore of Long Island, New York. J. Sedimentol. Petrol., 52:529-536.

Maldonado, A., and Stanley, D. J., 1981. Clay mineral distribution patterns as influenced by depositional processes in the Southeastern Levantine Sea. Sedimentology, 28:21-32.

Millot, G., 1970. Geology of Clays: New York (Springer-Verlag).

Mutti, E., and Ricci Lucchi, F., 1978. Turbidites of the northern Apennines: introduction to facies analysis. Int. Geol. Rev., 20:125-166.

Pevear, D. R., 1972. Source of Recent nearshore marine clays, southeastern United States. Geol. Soc. Am. Mem., 133:317-335.

Pollastro, R. M., 1982. A recommended procedure for the preparation or oriented clay-mineral specimens for X-ray diffraction analysis: modifications for Drever's filter-membrane peel technique. UiS. Geol. Surv. Open File Rept. 82-71.

Reinhardt, J., Christopher, R. A., and Owens, J. P., 1980. Lower Cretaceous stratigraphy of the core. Virginia Div. Min. Res. Pub., 20(3): $31-52$.

Rettke, R. C., 1981. Probable burial diagenetic and provenance effects on Dakota Group mineralogy, Denver Basin. J. Sedimentol. Petrol., 51:541-551.

Robertson, A. H. F., and Bliefnick, D. M., 1983. Sedimentology and origin of Lower Cretaceous pelagic carbonates and redeposited clastics, Blake-Bahama Formation, Deep Sea Drilling Project Site 534, western equatorial Atlantic. In Sheridan, R. E., Gradstein, F. M., et al., Init. Repts. DSDP, 76: Washington (U.S. Govt. Printing Office), 795-828.

Rohlf, F. J., and Sokal, R. R., 1969. Statistical Tables: San Francisco (W.H. Freeman and Co.).

Sheridan, R. E., Gradstein, F. M., et al., 1983. Site 534: Blake-Bahama Basin. In Sheridan, R. E., Gradstein, F. M., et al., Init. Repts. $D S D P, 76$ : Washington (U.S. Govt. Printing Office), 141-340.

Shipboard Scientific Party, 1972. Blake-Bahama Outer Ridge (southern end). In Hollister, C. D., Ewing, J. I., et al., Init. Repts. DSDP, 11: Washington (U.S. Govt. Printing Office), 105-134.

Soil Survey Staff, 1975. Soil Taxonomy. U.S. Dept. Agriculture, Agriculture Handbook No. 436, pp. 375-382.

Tucholke, B. E., Vogt, P. R., et al., 1979. Site 387: Cretaceous to Recent sedimentary evolution of the western Bermuda Rise. In Tucholke, B. E., Vogt, P. R., et al., Init. Repts. DSDP, 43: Washington (U.S. Govt. Printing Office), 323-391.

Weaver, C. E., 1967. The significance of clay minerals. In Nagy, B., and Colombo, U. (Eds.), Fundamental Aspects of Petroleum Geology: Amsterdam (Elsevier Publ. Co.), pp. 37-75.

Zemmels, I., Cook, H. E., and Hathaway, J. C., 1972. X-ray mineralogy studies-Leg 11. In Hollister, C. D., Ewing, J. I., et al., Init. Repts. DSDP, 11: Washington (U.S. Govt. Printing Office), 729790.

Date of Initial Receipt: 30 July 1985 Date of Acceptance: 12 June 1986 